\title{
Cordonnier Parasitic Complication
}

National Cancer Institute

\section{Source}

National Cancer Institute. Cordonnier Parasitic Complication. NCI Thesaurus. Code C138291.

Any parasite-focused infection complications occurring in allogeneic stem cell transplant recipients. 